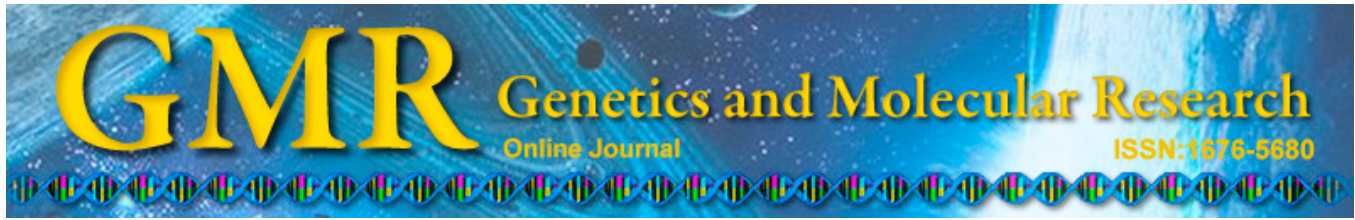

\title{
Mutagenic and antimutagenic effects of aqueous extract of rosemary (Rosmarinus officinalis L.) on meristematic cells of Allium cepa
}

\author{
I. Felicidade ${ }^{1,2}$, J.D. Lima ${ }^{1}$, J.R. Pesarini ${ }^{3,4}$, A.C.D. Monreal ${ }^{5}$, \\ M.S. Mantovani ${ }^{6}$, L.R. Ribeiro ${ }^{2,7}$ and R.J. Oliveira ${ }^{3,4,8}$ \\ ${ }^{1}$ Centro de Estudos em Nutrição e Genética Toxicológica, \\ Centro Universitário Filadélfia, Londrina, PR, Brasil \\ ${ }^{2}$ Programa de Pós-Graduação em Patologia, Faculdade de Medicina, \\ Universidade Estadual Paulista, Botucatu, SP, Brasil \\ ${ }^{3}$ Centro de Estudos em Célula Tronco, Terapia Celular e Genética Toxicológica, \\ Núcleo de Hospital Universitário, Universidade Federal de Mato Grosso do Sul, \\ Campo Grande, MS, Brasil \\ ${ }^{4}$ Programa de Pós-Graduação e Saúde em Desenvolvimento na Região \\ Centro-Oeste, Faculdade de Medicina "Dr. Hélio Mandetta", \\ Universidade Federal de Mato Grosso do Sul, Campo Grande, MS, Brasil \\ ${ }^{5}$ Centro de Ciências Biológicas e da Saúde, \\ Universidade Federal de Mato Grosso do Sul, Campo Grande, MS, Brasil \\ ${ }^{6}$ Departamento de Biologia Geral, Centro de Ciências Biológicas, \\ Universidade Estadual de Londrina, Londrina, PR, Brasil \\ ${ }^{7}$ Programa de Pós-Graduação em Biologia Celular e Molecular, \\ Universidade Estadual Paulista, Rio Claro, SP, Brasil \\ ${ }^{8}$ Programa de Mestrado em Farmácia, Centro de Ciências Biológicas e da Saúde, \\ Universidade Federal de Mato Grosso do Sul, Campo Grande, MS, Brasil
}

Corresponding author: R.J. Oliveira

E-mail: rodrigo.oliveira@ufms.br

Genet. Mol. Res. 13 (4): 9986-9996 (2014)

Received December 29, 2013

Accepted October 8, 2014

Published November 28, 2014

DOI http://dx.doi.org/10.4238/2014.November.28.3

ABSTRACT. Polyphenolic compounds present in rosemary were found to have antioxidant properties, anticarcinogenic activity, and to 
increase the detoxification of pro-carcinogens. The aim of the study was to determine the effect the aqueous extract of rosemary (AER) on mutagenicity induced by methylmethane sulfonate in meristematic cells of Allium cepa, as well as to describe its mode of action. Anti-mutagenicity experiments were carried out with 3 different concentrations of AER, which alone showed no mutagenic effects. In antimutagenicity experiments, AER showed chemopreventive activity in cultured meristematic cells of $A$. серa against exposure to methylmethane sulfonate. Additionally, post-treatment and simultaneous treatment using pre-incubation protocols were the most effective. Evaluation of different protocols and the percent reduction in DNA indicated bioantimutagenic as well desmutagenic modes of action for AER. AER may be chemopreventive and antimutagenic.

Key words: Antimutagenicity; Aqueous extract; Chemoprevention; DNA damage; Methylmethane sulfonate

\section{INTRODUCTION}

Fiskesjö $(1993,1994)$ reported the importance and utility of plant test systems for evaluating the risks of genotoxicity. Despite metabolic differences between plants and animals, a large number of similarities exist, indicating that Allium can be used to study processes that also occur in mammals.

Induction of direct or indirect DNA damage from genotoxic agents is inferred based on the production of chromosome aberrations (Jenkins et al., 2005). Thus, chemoprotective agents can be identified based on chromosome aberrations compared to a positive control of known effectiveness, which in this study was methylmethane sulfonate (MMS), based on a report by Rank and Nielsen (1997).

Interest in discovering natural agents that can protect DNA against damage induced by xenobiotics is increasing (Rigonato et al., 2004). Rosemary is an herb that contains agents with antimutagenic properties. This shrub is native to Europe but is cultivated in all states in Brazil (Dias et al., 2000).

The polyphenolic compounds found in rosemary have demonstrated antiproliferative effects in leukemia cells and may be used concomitantly with anticancer drugs (Steiner et al., 2001). These compounds also show hepatoprotective properties (Fahim et al., 1999), protective activity against carcinogens or agents toxic to the stomach (Singletary and Rokusek, 1997), and the potential to diminish the activation and increase the detoxification of the pro-carcinogen benzo[a]pyrene, indicating its chemopreventive activity (Offord et al., 1995).

Water was used as an extraction solvent for rosemary because according to Backleh et al. (2003), other solvents such as methanol is effective for extraction, non-toxic, and less expensive. Moreover, an aqueous extract is free of fats and chlorophyll. Additionally, rosemary tea is an extraction generally prepared by infusion using only water.

Previous studies have not been conducted examining the bioactivity of rosemary extract in cultured meristematic cells of Allium cepa seeds. Thus, the aim of the present study 
was to evaluate the mutagenicity and antimutagenicity of an aqueous extract of rosemary, as well as its mode of action, in cultured meristematic cells of A. cepa.

\section{MATERIAL AND METHODS}

\section{DNA damage-inducing agent}

DNA damage was induced using $10 \mu \mathrm{g} / \mathrm{mL}$ MMS (CAS 156890050, Acros Organics, Waltham, MA, USA). Its chemical structure is $\mathrm{C}_{2} \mathrm{H}_{6} \mathrm{O}_{3} \mathrm{~S}$. MMS was used to induce damage because it is an alkylating agent, which adds alkyl groups at various positions on DNA bases (Oga et al., 2008). Alkylating agents can induce a variety of deleterious modifications of the DNA strands, including adducts, cross-links, and breaks, which can be expressed as chromosomal (Jenkins et al., 2005) and micronucleus lesions.

\section{Preparation of aqueous extract of Rosmarinus officinalis L.}

The test material was an aqueous extract of Rosmarinus officinalis L. (rosemary). This bush exerts potent antioxidant activity primarily because of its polyphenolic components (Huang et al., 1994). The concentrations were 4.5, 9.0, and $18.0 \mu \mathrm{g} / \mathrm{mL}$ according to pilot experiments (data not shown).

Extraction was conducted according to the procedure described by Hsieh et al. (2007) with modifications. Rosemary leaves were collected from Centro Universitário Filadélfia (UniFil) medicinal plant gardens, Horto de Plantas Medicinais of UniFil, Londrina, PR, Brazil. This material was dried with circulating air $\left(40^{\circ} \mathrm{C}\right)$ and ground for use. In Centro de Estudos em Nutrição e Genética Toxicológica (CeNuGen-UniFil), the resulting leaf powder was extracted with boiling distilled water for $30 \mathrm{~min}$, and $200 \mathrm{~g}$ powder were placed in a beaker with $200 \mathrm{~mL}$ distilled water at $100^{\circ} \mathrm{C}$. This solution was mixed for $30 \mathrm{~min}$ at constant temperature in a closed environment to prevent evaporation. This procedure was carried out 3 times with the same powder. After filtration, the particulate matter was discarded and the solutions were pooled and lyophilized (Freeze dryer 8, Labconco, Kansas City, MO, USA). The extract was resuspended in distilled water for later use in the treatment of cultured meristematic cells of germinated A. cepa seeds.

\section{Experimental design and analysis methods}

Meristematic cells of $A$. cepa were used as the plant test system. The seeds (Isla ${ }^{\circledR}$; Lot: 21332A) were allowed to germinate at room temperature on Petri dishes, where they were covered with filter paper soaked with distilled water (Fernandes et al., 2007). They were then subjected to different treatments and protocols according to the method described by Oliveira et al. (2006) with modifications to evaluate mutagenicity and antimutagenicity.

To determine mutagenicity, the seeds were cultivated for $120 \mathrm{~h}$, followed by treatments with: a) control, b) MMS, and c) aqueous extract of rosemary (AER) at 3 different concentrations. In the control treatment, seeds were sown for $120 \mathrm{~h}$ in distilled water $(3 \mathrm{~mL})$. In MMS treatment, seeds were grown for $72 \mathrm{~h}$ in distilled water $(3 \mathrm{~mL})$, washed twice in distilled water, and subsequently transferred to plates containing $3 \mathrm{~mL}$ aqueous solution of $10 \mu \mathrm{g} / \mathrm{mL}$ MMS for $48 \mathrm{~h}$. To evaluate the effects of AER, the seeds were maintained for $72 \mathrm{~h}$ in distilled 
water ( $3 \mathrm{~mL}$ ), washed twice in distilled water, and then transferred to 3 different plates containing $3 \mathrm{~mL}$ aqueous AER solution at concentrations of $4.5,9.0$, or $18.0 \mu \mathrm{g} / \mathrm{mL}$. Treatments were carried out for $48 \mathrm{~h}$.

To determine the antimutagenic effect and mode of action of AER, the extract was combined with MMS according to the following protocols:

I) Pre-treatment; the seeds were sown in distilled water $(3 \mathrm{~mL})$ for $24 \mathrm{~h}$, washed twice in distilled water, and transferred to a plate containing AER solution $(3 \mathrm{~mL})$, where they remained for $48 \mathrm{~h}$. Next, the seeds were washed and allowed to grow for another $48 \mathrm{~h}$ in a plate containing MMS solution (3 mL).

II) Simple simultaneous: the seeds were sown in distilled water $(\mathrm{mL})$ for $72 \mathrm{~h}$, washed twice with distilled water, and transferred to a culture plate containing $3 \mathrm{~mL}$ solutions MMS and AER. These seeds were grown in the presence of both solutions for a period of $48 \mathrm{~h}$.

III) Simultaneous with pre-incubation: the aqueous solutions of MMS and AER were preincubated in a $37^{\circ} \mathrm{C}$ incubator for $1 \mathrm{~h}$ and then transferred to culture plates. The seeds germinated in this solution $(3 \mathrm{~mL})$ for $48 \mathrm{~h}$ were previously grown on another Petri plate for $72 \mathrm{~h}$ in the presence of distilled water $(3 \mathrm{~mL})$. Before transferring the seeds, they were washed twice with distilled water.

IV) Post-treatment: the seeds were cultivated for $24 \mathrm{~h}$ in distilled water $(3 \mathrm{~mL})$, then washed twice and transferred to a plate containing MMS solution $(3 \mathrm{~mL})$ for $48 \mathrm{~h}$. Next, the seeds were again washed twice in distilled water and transferred to a plate containing AER $(3 \mathrm{~mL})$.

All treatments and protocols were performed in triplicate. MMS solutions were $10 \mu \mathrm{g} /$ $\mathrm{mL}$, and the concentrations of AER solutions tested were 4.5, 9.0, and $18.0 \mu \mathrm{g} / \mathrm{mL}$.

After $120 \mathrm{~h}$ of cultivation, the roots were harvested at noon because the mitotic index was higher at this time, and the cells were then fixed in Carnoy's solution (3 ethanol:1 glacial acetic acid, 3:1) (Matsumoto et al., 2006) for at least $6 \mathrm{~h}$. Subsequently, the seeds were submitted to acid hydrolysis in $1 \mathrm{~N} \mathrm{HCl}$ at $60^{\circ} \mathrm{C}$ for 6 min and then treated with Schiff's reagent for $2 \mathrm{~h}$ in the dark. Seed tips were cut with a blade to extract the meristematic region and the tips were placed on a slide. A drop of acetic carmin $(2 \%)$ was later added to intensify the cytoplasmic staining of meristematic cells (Fernandes et al., 2007). A coverslip was applied with slight pressure to provide a better spread of cells on the slide. The coverslip was removed with the aid of liquid nitrogen. The slide with the material was allowed to dry at room temperature for $24 \mathrm{~h}$, and a new coverslip was added with a drop of Permout ${ }^{\mathbb{B}}$ placed on the biological material. The slides were analyzed on the following day.

A total of 15,000 cells/treatment ( 1000 cells/slide; 3 replications) were analyzed using a light microscope at 400X magnification. To determine the mitotic index, the number of cells in the different phases of mitosis (prophase, metaphase, anaphase, and telophase) was divided by the total number of cells. To determine the total frequency of aberrations, the total number of aberrations was divided by the total number of cells.

\section{Calculation of damage reduction percentage}

The MMS damage reduction percentage by $R$. officinalis L. was calculated as the difference in average positive controls minus the mean number of damaged cells with combination divided by the difference between damaged positive and negative control cells. The result was multiplied by 100 and expressed as the damage reduction percentage (Waters et al., 1990; Oliveira et al., 2009). Statistical analysis was performed by analysis of variance/Tukey. The differences were significant when $\mathrm{P}<0.05$. 


\section{RESULTS}

MMS induced chromosome aberrations including anaphasic bridges, multipolar anaphase, nuclear budding, chromosome breaks and bridges in metaphase, anaphase and telophase, and micronuclei in the mutagenicity test in $A$. серa. Table 1 shows the mutagenicity data for the 3 concentrations of AER tested; none of the concentrations showed statistically significant mutagenic activity.

Table 1. Chromosomal aberrations, means and SE, total frequency of aberrations, and mitotic index determined in 15,000 meristematic cells of Allium cepa exposed to MMS and AER, using the protocol of mutagenicity.

\begin{tabular}{|c|c|c|c|c|c|c|c|c|c|c|c|c|c|c|}
\hline \multirow[t]{2}{*}{ Treatment } & \multirow[t]{2}{*}{ Concentration } & \multicolumn{10}{|c|}{ Chromosomal aberrations } & \multirow[t]{2}{*}{ Mean $\pm \mathrm{SE}$} & \multicolumn{2}{|c|}{ TFA (\%) MI (\%) } \\
\hline & & $\mathrm{MN}$ & $\mathrm{AB}$ & MA & NB & BM & BA & BT & $\mathrm{CBM}$ & CBA & CBT & & & \\
\hline \multicolumn{15}{|c|}{ Mutagenicity } \\
\hline Control & & 6 & 3 & 14 & 0 & 0 & 0 & 0 & 6 & 3 & 1 & $11.00 \pm 1.53^{\mathrm{a}}$ & a $\quad 0.22$ & $6.25^{\mathrm{a}}$ \\
\hline MMS & $10.0 \mu \mathrm{g} / \mathrm{mL}$ & 153 & 27 & 51 & 5 & 15 & 15 & 3 & 26 & 16 & 3 & $104.67 \pm 3.67^{b}$ & b $\quad 2.00$ & $5.77^{\mathrm{a}}$ \\
\hline \multirow[t]{3}{*}{ AER } & $4.5 \mu \mathrm{g} / \mathrm{mL}$ & 17 & 5 & 25 & 0 & 5 & 0 & 2 & 4 & 1 & 1 & $20.00 \pm 2.00^{\mathrm{a}}$ & a $\quad 0.40$ & $4.39^{\mathrm{a}}$ \\
\hline & $9.0 \mu \mathrm{g} / \mathrm{mL}$ & 27 & 8 & 18 & 1 & 1 & 3 & 0 & 3 & 3 & 0 & $21.33 \pm 0.88^{\mathrm{a}}$ & a $\quad 0.42$ & $3.77^{\mathrm{a}}$ \\
\hline & $18.0 \mu \mathrm{g} / \mathrm{mL}$ & 19 & 9 & 10 & 1 & 4 & 3 & 0 & 4 & 2 & 0 & $17.33 \pm 2.19^{\mathrm{a}}$ & 0.34 & $4.23^{\mathrm{a}}$ \\
\hline
\end{tabular}

$\mathrm{SE}=$ standard error; MMS = methylmethane sulfonate; $\mathrm{AER}=$ aqueous extract of rosemary. TFA $(\%)=$ total frequency of aberrations (expressed as a percentage); $\mathrm{MI}(\%)=$ mitotic index (expressed as a percentage). $\mathrm{MN}=$ micronucleus $; \mathrm{AB}=$ anaphasic bridge; $\mathrm{MA}=$ multipolar anaphase; $\mathrm{NB}=$ nuclear bud; $\mathrm{BM}=$ chromosomal break in metaphase; $\mathrm{BA}=$ chromosomal break in anaphase; $\mathrm{BT}=$ chromosomal break in telophase; $\mathrm{CBM}=$ chromosomal bridge in metaphase; $\mathrm{CBA}=$ chromosomal bridge in anaphase; $\mathrm{CBT}=$ chromosomal bridge in telophase. ${ }^{\mathrm{a}, \mathrm{b}}$ Letters indicate statistically different results $(\mathrm{P}<0.05$, analysis of variance/Tukey).

Tables 2-5 show the data obtained from the antimutagenicity experiments using 4 different protocols: pre-treatment, simple simultaneous, simultaneous with pre-incubation, and post-treatment. The types of chromosome aberrations, means and standard deviation of the total number of chromosome aberrations, total frequency of aberrations, mitotic index, and percent reduction in DNA damage are also shown.

Table 2. Chromosomal aberrations, means and SE, total frequency of aberrations, mitotic index, and percent reduction in DNA damage, determined in 15,000 meristematic cells of Allium cepa exposed to MMS and $\mathrm{AER}$, in the evaluation of the antimutagenicity referring to the protocol of pre-treatment.

\begin{tabular}{|c|c|c|c|c|c|c|c|c|c|c|c|c|c|c|c|}
\hline \multirow[t]{2}{*}{ Treatment } & \multirow[t]{2}{*}{ Concentration } & \multicolumn{10}{|c|}{ Chromosomal aberrations } & \multirow[t]{2}{*}{ Mean \pm SE } & \multirow[t]{2}{*}{ TFA $(\%)$} & \multirow[t]{2}{*}{ MI (\%) } & \multirow[t]{2}{*}{ DR $(\%)$} \\
\hline & & $\mathrm{MN}$ & $\mathrm{AB}$ & MA & NB & $\mathrm{BM}$ & $\mathrm{BA}$ & BT & $\mathrm{CBM}$ & CBA & CBT & & & & \\
\hline \multicolumn{16}{|c|}{ Antimutagenicity } \\
\hline Control & & 6 & 3 & 14 & 0 & 0 & 0 & 0 & 6 & 3 & 1 & 11.00 & 0.22 & $6.25^{\mathrm{a}}$ & NA \\
\hline MMS & $10.0 \mu \mathrm{g} / \mathrm{mL}$ & 153 & 27 & 51 & 5 & 15 & 15 & 3 & 26 & 16 & 3 & $104.67 \pm 3.67^{b}$ & 2.00 & $5.77^{\mathrm{a}}$ & NA \\
\hline \multirow[t]{3}{*}{$\mathrm{AER}+\mathrm{MMS}$} & $4.5 \mu \mathrm{g} / \mathrm{mL}$ & 63 & 13 & 22 & 0 & 4 & 10 & 0 & 20 & 5 & 2 & $47.00 \pm 1.53^{\mathrm{c}}$ & 0.90 & $6.16^{\mathrm{a}}$ & 61.57 \\
\hline & $9.0 \mu \mathrm{g} / \mathrm{mL}$ & 65 & 24 & 11 & 1 & 13 & 10 & 3 & 21 & 11 & 2 & $53.67 \pm 5.33^{\mathrm{c}}$ & 1.06 & $6.55^{\mathrm{a}}$ & 54.45 \\
\hline & $18.0 \mu \mathrm{g} / \mathrm{mL}$ & 84 & 11 & 29 & 0 & 6 & 3 & 2 & 22 & 4 & 4 & $55.33 \pm 6.01^{\mathrm{c}}$ & 1.09 & $4.41^{\mathrm{a}}$ & 52.67 \\
\hline
\end{tabular}

$\mathrm{SE}=$ standard error; $\mathrm{MMS}=$ methylmethane sulfonate; $\mathrm{AER}=$ aqueous solution of aqueous extract of rosemary. TFA $(\%)=$ total frequency of aberrations (expressed as a percentage). MI $(\%)=$ mitotic index (expressed as a percentage). DR $(\%)=$ damage reduction (expressed as a percentage). $\mathrm{NA}=$ not applicable; $\mathrm{MN}=$ micronucleus; $\mathrm{AB}=$ anaphasic bridge; $\mathrm{MA}=$ multipolar anaphase; $\mathrm{NB}=$ nuclear bud; $\mathrm{BM}=$ chromosomal break in metaphase; $\mathrm{BA}=$ chromosomal break in anaphase; $\mathrm{BT}=$ chromosomal break in telophase $; \mathrm{CBM}=$ chromosomal bridge in metaphase; $\mathrm{CBA}=$ chromosomal bridge in anaphase; $\mathrm{CBT}=$ chromosomal bridge in telophase. ${ }^{\mathrm{a}, \mathrm{b}, \mathrm{c}}$ Letters indicate statistically different results $(\mathrm{P}<0.05$, analysis of variance/Tukey). 
Table 3. Chromosomal aberrations, means and SE, total frequency of aberrations, mitotic index, and percent reduction in DNA damage, determined in 15,000 meristematic cells of Allium cepa exposed to MMS and $\mathrm{AER}$, in the evaluation of the antimutagenicity referring to the protocol of simple simultaneous.

\begin{tabular}{|c|c|c|c|c|c|c|c|c|c|c|c|c|c|c|c|}
\hline \multirow[t]{2}{*}{ Treatment } & \multirow[t]{2}{*}{ Concentration } & \multicolumn{10}{|c|}{ Chromosomal aberrations } & \multirow[t]{2}{*}{ Mean $\pm \mathrm{SE}$} & \multirow[t]{2}{*}{ TFA (\%) } & \multirow[t]{2}{*}{ MI (\%) } & \multirow[t]{2}{*}{ DR $(\%)$} \\
\hline & & $\mathrm{MN}$ & $\mathrm{AB}$ & MA & NB & $\mathrm{BM}$ & BA & BT & $\mathrm{CBM}$ & CBA & CBT & & & & \\
\hline \multicolumn{16}{|l|}{ Antimutagenicity } \\
\hline Control & & 6 & 3 & 14 & 0 & 0 & 0 & 0 & 6 & 3 & 1 & $11.00 \pm 1.53^{\mathrm{a}}$ & 0.22 & $6.25^{\mathrm{a}}$ & NA \\
\hline MMS & $10.0 \mu \mathrm{g} / \mathrm{mL}$ & 153 & 27 & 51 & 5 & 15 & 15 & 3 & 26 & 16 & 3 & $104.67 \pm 3.67^{b}$ & 2.00 & $5.77^{\mathrm{a}}$ & NA \\
\hline \multirow[t]{3}{*}{$\mathrm{AER}+\mathrm{MMS}$} & $4.5 \mu \mathrm{g} / \mathrm{mL}$ & 104 & 12 & 32 & 0 & 3 & 4 & 0 & 9 & 3 & 6 & $58.33 \pm 3.33^{\mathrm{c}}$ & c 1.12 & $8.02^{\mathrm{a}}$ & 49.47 \\
\hline & $9.0 \mu \mathrm{g} / \mathrm{mL}$ & 77 & 17 & 25 & 1 & 7 & 4 & 0 & 7 & 3 & 0 & $47.00 \pm 1.73^{\mathrm{c}}$ & $=0.91$ & $6.59^{\mathrm{a}}$ & 61.57 \\
\hline & $18.0 \mu \mathrm{g} / \mathrm{mL}$ & 62 & 27 & 48 & 3 & 1 & 3 & 3 & 14 & 2 & 3 & $55.33 \pm 3.53^{\circ}$ & - 1.09 & $6.86^{\mathrm{a}}$ & 52.6 \\
\hline
\end{tabular}

$\mathrm{SE}=$ standard error; $\mathrm{MMS}=$ methylmethane sulfonate; $\mathrm{AER}=$ aqueous solution of aqueous extract of rosemary. TFA $(\%)=$ total frequency of aberrations (expressed as a percentage). MI $(\%)=$ mitotic index (expressed as a percentage). $\mathrm{DR}(\%)=$ damage reduction (expressed as a percentage). $\mathrm{NA}=$ not applicable; $\mathrm{MN}=$ micronucleus; $\mathrm{AB}=$ anaphasic bridge; $\mathrm{MA}=$ multipolar anaphase $\mathrm{NB}=$ nuclear bud; $\mathrm{BM}=$ chromosomal break in metaphase; $\mathrm{BA}=$ chromosomal break in anaphase $; \mathrm{BT}=$ chromosomal break in telophase $; \mathrm{CBM}=$ chromosomal bridge in metaphase; $\mathrm{CBA}=$ chromosomal bridge in anaphase; $\mathrm{CBT}=$ chromosomal bridge in telophase. ${ }^{\mathrm{a}, \mathrm{b}, \mathrm{c}}$ Letters indicate statistically different results $(\mathrm{P}<0.05$, analysis of variance/Tukey).

Table 4. Chromosomal aberrations, means and SE, total frequency of aberrations, mitotic index, and percentage of reduction of damage to DNA, tested at 15,000 meristematic cells of Allium cepa exposed to MMS and the AER, in the evaluation of the mutagenicity referring to the protocol of simultaneous with pre-incubation.

\begin{tabular}{|c|c|c|c|c|c|c|c|c|c|c|c|c|c|c|c|}
\hline \multirow[t]{2}{*}{ Treatment } & \multirow[t]{2}{*}{ Concentration } & \multicolumn{10}{|c|}{ Chromosomal aberrations } & \multirow[t]{2}{*}{ Mean \pm SE } & \multirow[t]{2}{*}{ TFA $(\%)$} & \multirow[t]{2}{*}{ MI (\%) } & \multirow[t]{2}{*}{ DR $(\%)$} \\
\hline & & $\mathrm{MN}$ & $\mathrm{AB}$ & MA & NB & $\mathrm{BM}$ & $\mathrm{BA}$ & $\mathrm{BT}$ & $\mathrm{CBM}$ & CBA & CBT & & & & \\
\hline \multicolumn{16}{|c|}{ Antimutagenicity } \\
\hline Control & & 6 & 3 & 14 & 0 & 0 & 0 & 0 & 6 & 3 & 1 & $11.00 \pm 1.53^{\mathrm{a}}$ & 0.22 & $6.25^{\mathrm{a}, \mathrm{b}}$ & NA \\
\hline MMS & $10.0 \mu \mathrm{g} / \mathrm{mL}$ & 153 & 27 & 51 & 5 & 15 & 15 & 3 & 26 & 16 & 3 & $104.67 \pm 3.67^{b}$ & 2.00 & $5.77^{\mathrm{a}, \mathrm{b}}$ & NA \\
\hline \multirow[t]{3}{*}{$\mathrm{AER}+\mathrm{MMS}$} & $4.5 \mu \mathrm{g} / \mathrm{mL}$ & 57 & 13 & 20 & 0 & 1 & 6 & 1 & 13 & 6 & 0 & $39.00 \pm 1.53^{\mathrm{c}}$ & 0.77 & $8.31^{\mathrm{a}}$ & 70.11 \\
\hline & $9.0 \mu \mathrm{g} / \mathrm{mL}$ & 29 & 19 & 42 & 0 & 1 & 5 & 2 & 6 & 1 & 0 & $35.00 \pm 1.53^{c}$ & 0.69 & $9.16^{\mathrm{a}}$ & 74.38 \\
\hline & $18.0 \mu \mathrm{g} / \mathrm{mL}$ & 82 & 13 & 19 & 1 & 0 & 1 & 0 & 1 & 1 & 0 & $39.33 \pm 1.86^{\mathrm{c}}$ & 0.78 & $4.58^{\mathrm{b}}$ & 69.75 \\
\hline
\end{tabular}

$\mathrm{SE}=$ standard error; MMS = methylmethane sulfonate; $\mathrm{AER}=$ aqueous solution of aqueous extract of rosemary. TFA $(\%)=$ total frequency of aberrations (expressed as a percentage). MI $(\%)=$ mitotic index (expressed as a percentage). DR (\%) = damage reduction (expressed as a percentage). $\mathrm{NA}=$ not applicable; $\mathrm{MN}=$ micronucleus; $\mathrm{AB}=$ anaphasic bridge; $\mathrm{MA}=$ multipolar anaphase; $\mathrm{NB}=$ nuclear bud; $\mathrm{BM}=$ chromosomal break in metaphase; $\mathrm{BA}=$ chromosomal break in anaphase; $\mathrm{BT}=$ chromosomal break in telophase $; \mathrm{CBM}=$ chromosomal bridge in metaphase; $\mathrm{CBA}=$ Chromosomal bridge in anaphase; $\mathrm{CBT}=$ chromosomal bridge in telophase. ${ }^{\mathrm{a}, \mathrm{b}, \mathrm{c}}$ Letters indicate statistically different results $(\mathrm{P}<0.05$, analysis of variance/Tukey).

In the pre-treatment protocol (Table 2), the addition of AER to MMS effectively prevented damage caused by the indirect action of the mutagen for the 3 concentrations of AER tested in meristematic cells of $A$. сеpa roots. The mean values for chromosome alterations for this protocol varied from 47.00-55.33. The percent reduction in DNA damage was 61.57, 54.45 , and $52.67 \%$ for extract concentrations of $4.5,9.0$, and $18.0 \mu \mathrm{g} / \mathrm{mL}$, respectively.

Simple simultaneous treatment (Table 3) demonstrated considerable reduction in DNA damage for the 3 concentrations of AER tested. The means of the frequency of alterations in DNA varied from 47.00-58.33 and the percent reduction in DNA damage was 49.47, 61.57 , and 52.67 for $4.5,9.0$, and $18.0 \mu \mathrm{g} / \mathrm{mL}$, respectively.

Chemopreventive activity was observed in the simultaneous treatment with pre-incubation (Table 4) at all concentrations tested. The means for chromosome alterations were $39.00,35.00$, and 39.33 and the percent reductions in DNA damage were 70.11, 74.38, and $69.75 \%$ for the concentrations of $4.5,9.0$, and $18.0 \mu \mathrm{g} / \mathrm{mL}$, respectively. 
Table 5. Chromosomal aberrations, mean and SE, total frequency of aberrations, mitotic index, and percentage of reduction of damage to DNA, tested at 15,000 meristematic cells of Allium cepa exposed to MMS and the $\mathrm{AER}$, in the evaluation of the mutagenicity referring to the protocol of post-treatment.

\begin{tabular}{|c|c|c|c|c|c|c|c|c|c|c|c|c|c|c|c|}
\hline \multirow[t]{2}{*}{ Treatment } & \multirow[t]{2}{*}{ Concentration } & \multicolumn{10}{|c|}{ Chromosomal aberrations } & \multirow[t]{2}{*}{ Mean \pm SE } & \multirow[t]{2}{*}{ TFA $(\%)$} & \multirow[t]{2}{*}{ MI (\%) } & \multirow[t]{2}{*}{$\mathrm{DR}(\%)$} \\
\hline & & $\mathrm{MN}$ & $\mathrm{AB}$ & MA & NB & BM & BA & BT & CBM & CBA & CBT & & & & \\
\hline \multicolumn{16}{|c|}{ Antimutagenicity } \\
\hline Control & & 6 & 3 & 14 & 0 & 0 & 0 & 0 & 6 & 3 & 1 & $11.00 \pm 1.53^{\mathrm{a}}$ & 0.22 & $6.25^{\mathrm{a}}$ & NA \\
\hline MMS & $10.0 \mu \mathrm{g} / \mathrm{mL}$ & 153 & 27 & 51 & 5 & 15 & 15 & 3 & 26 & 16 & 3 & $104.67 \pm 3.67^{b}$ & 2.00 & $5.77^{\mathrm{a}}$ & NA \\
\hline \multirow[t]{3}{*}{$\mathrm{MMS}+\mathrm{AER}$} & $4.5 \mu \mathrm{g} / \mathrm{mL}$ & 52 & 13 & 25 & 0 & 5 & 7 & 1 & 23 & 14 & 1 & $47.00 \pm 2.52^{c}$ & 0.92 & $8.19^{\mathrm{a}}$ & 61.57 \\
\hline & $9.0 \mu \mathrm{g} / \mathrm{mL}$ & 72 & 10 & 19 & 1 & 6 & 5 & 0 & 14 & 8 & 1 & $45.33 \pm 5.49^{c}$ & 0.88 & $6.95^{\mathrm{a}}$ & 63.35 \\
\hline & $18.0 \mu \mathrm{g} / \mathrm{mL}$ & 48 & 16 & 17 & 0 & 1 & 1 & 1 & 11 & 2 & 0 & $32.33 \pm 3.48^{c}$ & 0.63 & $7.64^{\mathrm{a}}$ & 77.22 \\
\hline
\end{tabular}

$\mathrm{SE}=$ standard error; $\mathrm{MMS}=$ methylmethane sulfonate; $\mathrm{AER}=$ aqueous solution of aqueous extract of rosemary. TFA $(\%)=$ total frequency of aberrations (expressed as a percentage). MI $(\%)=$ mitotic index (expressed as a percentage). DR $(\%)=$ damage reduction (expressed as a percentage). $\mathrm{NA}=$ not applicable; $\mathrm{MN}=$ micronucleus; $\mathrm{AB}=$ anaphasic bridge; $\mathrm{MA}=$ multipolar anaphase $\mathrm{NB}=$ nuclear bud; $\mathrm{BM}=$ chromosomal break in metaphase; $\mathrm{BA}=$ chromosomal break in anaphase $\mathrm{BT}=$ chromosomal break in telophase; $\mathrm{CBM}=$ chromosomal bridge in metaphase; $\mathrm{CBA}=$ chromosomal bridge in anaphase; $\mathrm{CBT}=$ chromosomal bridge in telophase. ${ }^{\mathrm{a}, \mathrm{b}, \mathrm{c}}$ Letters indicate statistically different results $(\mathrm{P}<0.05$, analysis of variance/Tukey).

The post-treatment protocol (Table 5) demonstrated that all concentrations of AER prevented DNA damage caused by MMS. The percent reductions in DNA damage were 61.57, 63.35 , and $77.22 \%$ for $4.5,9.0$, and $18.0 \mu \mathrm{g} / \mathrm{mL}$, respectively, and the means for chromosome aberrations varied from 32.33-47.00.

Based on these results and the chemopreventive effectiveness in the different protocols, it was necessary to determine the rates of increase and/or decrease of this activity for simple simultaneous treatment (Table 6). We divided the percent reduction in DNA damage for the different treatments in the simple simultaneous protocol by the corresponding treatments in the other protocols, multiplied these values by 100, and subtracted the product from 100 (Oliveira et al., 2006). The protocol for simple simultaneous treatment gave the highest chemopreventive activity as there was a decrease in the percent reduction of DNA damage for all concentrations in the simultaneous protocol with pre-incubation, with the decrease varying from -17.22 to -29.44 , but for the post-treatment protocol the variation was -2.81 to -31.79 . For the pre-treatment protocol, a decrease of -19.65 was found for the lowest concentration and an increase of 13.08 for the intermediate concentration. The highest concentration showed no change. The mitotic indices did not change regardless of the treatment compared with the control.

Table 6. Percent increase or decrease in antimutagenic activity of aqueous extract of rosemary for the different treatment protocols compared to the simultaneous simple protocol.

\begin{tabular}{lccr}
\hline Concentration & & Protocols & Post-treatment \\
\cline { 2 - 4 } & Pre-treatment & Simultaneous with pre-incubation & -19.65 \\
\hline $.5 \mu \mathrm{g} / \mathrm{mL}$ & -19.65 & -29.44 & -2.81 \\
$9.0 \mu \mathrm{g} / \mathrm{mL}$ & +13.08 & -17.22 & -31.79 \\
$18.0 \mu \mathrm{g} / \mathrm{mL}$ & 0.00 & -24.49 & \\
\hline
\end{tabular}

\section{DISCUSSION}

Various models are available for studying mutagenesis and antimutagenesis; the most widely used models include in vitro studies with cultured mammalian and plant cells and in vivo studies that utilize laboratory animals and some plant species as environmental indicators. 
To identify the causative agents of DNA damage or agents that can protect against such effects, plants are particularly useful because of their low cost and ease of use. Thus, some species, such as A. cepa, are utilized as indicator organisms in studies of mutagenesis to predict risks in higher eukaryotes such as mammals.

Plant systems have a variety of well-defined genetic alterations that can be caused by xenobiotics, including alterations in ploidy, chromosome aberrations, and sister chromatid exchanges (Grant, 1994). These alterations can also occur in assays with mammals exposed to the same compounds.

Additionally, dietary constituents can suppress the genotoxic action or damage of xenobiotics through various intra- and extracellular mechanisms (el Hamss and Idaomar, 2002). Thus, the present investigation used the $A$. cepa system to examine the chemopreventive capacity of the aqueous extract of rosemary and its mode of action.

In the present study, MMS was utilized as the DNA damage-inducing agent. This substance is classified as an alkylating agent; it causes the transfer of methyl groups to nitrogenous bases of DNA, leading to altered base pairing, which can introduce transitions, transversions, and reading frame changes, as well as induce chromosome breaks. This is because some alkylating agents, particularly bifunctional agents, can cause DNA-DNA or DNAprotein crosslinks (Snustad and Simmons, 2001). For studies in cultured meristematic cells of A. cepa, Rank and Nielsen (1997) demonstrated that MMS is effective chemical agent as a positive control and that the main alterations observed include multiple chromosome aberrations such as anaphasic bridges, c-metaphases, chromosome breaks, chromatid breaks, and chromosomes in rings, as well as micronucleus formation and budding, among others.

Treatment of cultured meristematic cells of $A$. cepa exposed to MMS with AER efficiently prevented these alterations for all concentrations and protocols tested.

In the pre-treatment protocol in which the cultures were first treated with AER and then exposed to MMS, the percent reduction in DNA damage varied from 52.67-61.57\%. We observed a decrease in chemopreventive activity and an increase in extract concentration. It can be inferred that there was an interaction between MMS and the bioactive principles in the rosemary extract inside the cell, which prevented MMS from causing DNA damage. Another possibility is that upon entering the cell, the bioactive principles of rosemary modulated the repair system of the cell, making it more efficient and thus decreasing the mutation rate. If these 2 hypotheses are considered to account for the chemopreventive activity of the extract, the first involves desmutagenesis, while the second involves bioantimutagenesis.

For the simple simultaneous treatment protocol, cultured meristematic cells of $A$. cepa were exposed to the mutagenic agent and antimutagenic extract simultaneously. Thus, if the activity involved desmutagenesis, inactivation of MMS by the rosemary extract could occur in both the extracellular and intracellular milieu as the added compounds could enter the cell at the same time. Upon entering the cell, MMS can react directly with DNA, causing mutations. However, AER may simultaneously modulate the repair system, increasing its efficacy and fidelity, which could thereby affect bioantimutagenic activity. These activities were further verified based on the percent reduction in DNA damage, which varied from 49.47-61.57\%. For this protocol, no dose-response correlation was observed.

For the protocol involving simultaneous exposure with pre-incubation, during which the test solutions were incubated together at $37^{\circ} \mathrm{C}$ for $1 \mathrm{~h}$, the percent reduction in DNA damage varied from 69.75-74.38. These values show no dose-response relationship and the prior contact of the 2 solutions, indicating that MMS can be inactivated by the rosemary extract before reaching 
the A. cepa cell DNA, suggesting that AER acts preferentially through desmutagenesis.

Finally, in the post-treatment protocol, cells were first exposed to MMS and then to AER. Thus, this protocol indicates that the chemoprotective activity occurs through bioantimutagenesis; AER may be capable of modulating the repair system, increasing its efficiency and/or fidelity. Additionally, DNA damage was significantly reduced and varied from $61.57-77.22 \%$.

The analysis of the increase and decrease in the percent reduction of DNA damage demonstrated that the simple simultaneous protocol showed the greatest chemopreventive activity. Post-treatment and simultaneous pre-incubation showed decreased efficacy and pretreatment showed a decrease in efficacy with the lowest concentration and diminished efficacy with the intermediate concentration. However, the highest extract concentration showed the same effect as the simple simultaneous protocol. This finding supports the hypothesis that AER can act through desmutagenesis as well as through bioantimutagenesis. Additionally, the percent reduction in DNA damage was similar, indicating that the antimutagenic activity of the extract occurred through both modes of action.

In general, there are 2 classes of DNA protective substances: desmutagenic and bioantimutagenic. Desmutagenic substances are those capable of preventing the action of damage-inducing agents, mainly through adsorption, thus acting preferentially in the extracellular medium. In contrast, bioantimutagenic agents can prevent lesions to DNA or its repair, acting inside the cell (Kada and Shimoi, 1987). However, De Flora (1998) reported that bioantimutagenic substances modulate DNA repair and replication, stimulate error-free repair of DNA damage, or inhibit repair systems that are subject to error. To elucidate the mode of action of molecules or chemical agents in antimutagenicity, it is necessary to use different treatment protocols (Flagg et al., 1995). We examined 3 of these protocols, including pre-treatment, simultaneous treatment with 2 variations (simple and with pre-incubation), and post-treatment, as suggested by Oliveira et al. (2006, 2007).

Because simple simultaneous treatment showed both desmutagenic and bioantimutagenic activity, simultaneous treatment with pre-incubation indicated desmutagenic activity, while pre-treatment and post-treatment showed bioantimutagenic activity. Analysis of CHO$\mathrm{k} 1$ cells indicated that the mode of action of the AER was both desmutagenic and bioantimutagenic. A similar study was carried out by Oliveira et al. $(2006,2007)$, who examined the mode of action of $\beta$-glucan. These authors reported that different $\beta$-glucans possess the same mode of action, as well as that bioantimutagenesis plays a less important role than desmutagenesis.

The extract itself showed no mutagenic activity at the concentrations tested, indicating that it cannot induce the initiation of cancer cells.

These results agree with those of Kohlmeier et al. (1995), who found that flavonoid and polyphenolic compounds could act as antimutagenic agents. Flavonoids are thought to possess good activity via desmutagenesis and polyphenolic compounds act via bioantimutagenesis and desmutagenesis by modulating enzymes and antioxidant activity.

According to Steiner et al. (2001), the bioactive principles in rosemary can act as antioxidants, which explains the antimutagenic action described in this study. Antioxidant agents comprise the principal group of inhibitors of carcinogenesis, as they are free radical scavengers. Additionally, they inhibit carcinogenesis, induce cell death, inhibit enzymes such as cytochrome P450 enzymes, and inhibit angiogenesis, growth factor antagonists, and DNA lesion repair agents (Kelloff et al., 1999).

Even at low concentrations, antioxidants can slow or inhibit oxidation (Sies, 1993; 
Maxwell, 1995). The most widely used classification system divides them into 2 systems: enzymatic, composed of enzymes produced in the organism, and non-enzymatic, composed of vitamins, flavonoids, lycopenes, and bilirubins (Sies, 1993); rosemary extract is included in the second group. Foods containing antioxidant agents are 1 of the main groups with functional properties, known also as nutraceuticals or pharmaco-foods (Ferrari and Torres, 2002).

The antimutagenic activity of compounds present in rosemary was examined in the micronucleus test before and after irradiation with gamma rays by Del Baño et al. (2006). In accordance with the diminution in the frequency of micronuclei, the compounds found in rosemary are antimutagenic. Haraguchi et al. (1995) demonstrated that the polyphenolic compounds in rosemary are efficient protectors of biological systems against oxidative stress.

Because oxidative stress places a cell at risk of initiating a carcinogenic process because of mutagenic events, the efficiency of these antioxidant compounds in rosemary in protecting biological systems against these processes indicates that this herb has antimutagenic and anticarcinogenic activities. The results of Cheung and Tai (2007) support our results; they showed that compounds present in rosemary have a variety of pharmacological activities, including chemopreventive activity and their potential use in cancer treatment, as these compounds exert antiproliferative activity in human leukemia and breast cancer cells.

\section{ACKNOWLEDGMENTS}

Research supported by Centro Universitário Filadélfia (UNIFIL), Pró-Reitoria de Pesquisa e Pós-Graduação, Londrina, PR, Brazil. We also thank Isabel Florentino for help with the extracts.

\section{REFERENCES}

Backleh M, Leupold G and Parlar H (2003). Rapid quantitative enrichment of carnosic acid from rosemary (Rosmarinus officinalis L.) by isoelectric focused adsorptive bubble chromatography. J. Agric. Food Chem. 51: 1297-1301.

Cheung S and Tai J (2007). Anti-proliferative and antioxidant properties of rosemary Rosmarinus officinalis. Oncol. Rep. 17: 1525-1531.

De Flora S (1998). Mechanisms of inhibitors of mutagenesis and carcinogenesis. Mutat. Res. 402: 151-158.

Del Baño MJ, Castillo J, Benavente-García O, Lorente J, et al. (2006). Radioprotective-antimutagenic effects of rosemary phenolics against chromosomal damage induced in human lymphocytes by $\gamma$-rays. J. Agric. Food Chem. 54: 20642068.

Dias PC, Foglio MA, Possenti A and de Carvalho JE (2000). Antiulcerogenic activity of crude hydroalcoholic extract of Rosmarinus officinalis L. J. Ethnopharmacol. 69: 57-62.

el Hamss R and Idaomar M (2002). Antimutagens and anticarcinogenic agents, identification and mechanisms of action of food xenobiotics. Therapie 57: 512-517.

Fahim FA, Esmat AY, Fadel HM and Hassan KF (1999). Allied studies on the effect of Rosmarinus officinalis L. on experimental hepatotoxicity and mutagenesis. Int. J. Food Sci. Nutr. 50: 413-427.

Fernandes TCC, Mazzeo DEC and Morales MAM (2007). Mechanism of micronuclei formation in polyploidizated cells of Allium cepa exposed to trifluralin herbicide. Pestic. Biochem. Physiol. 88: 252-259.

Ferrari CKB and Torres EAFS (2002). New dietetic compounds with anticarcinogenic properties. Rev. Bras. Cancerol. 48: 375-382.

Fiskesjö G (1993). The Allium test. In: wastewater monitoring. Environ. Toxicol. Water Qual. 8: 291-298.

Fiskesjö G (1994). The Allium Test II: Assessment of chemical's genotoxic potential by recording aberrations in chromosomes and cell divisions in root tips of Allium cepa L. Environ. Toxicol. Water Qual. 9: 234-241.

Flagg EW, Coates RJ and Greenberg RS (1995). Epidemiologic studies of antioxidants and cancer in humans. J. Am. Coll. Nutr. 14: 419-427.

Grant WF (1994). The present status of higher plant bioassays for the detection of environmental mutagens. Mutat. Res. 
310: $175-185$.

Haraguchi H, Saito T, Okamura N and Yagi A (1995). Inhibition of lipid peroxidation and superoxide generation by diterpenoids from Rosmarinus officinalis. Planta Med. 61: 333-336.

Hsieh CL, Peng CH, Chyau CC, Lin YC, et al. (2007). Low-density lipoprotein, collagen, and thrombin models reveal that Rosemarinus officinalis L. exhibits potent antiglycative effects. J. Agric. Food Chem. 55: 2884-2891.

Huang MT, Ho CT, Wang ZY, Ferraro T, et al. (1994). Inhibition of skin tumorigenesis by rosemary and its constituents carnosol and ursolic acid. Cancer Res. 54: 701-708.

Jenkins GJ, Doak SH, Johnson GE, Quick E, et al. (2005). Do dose response thresholds exist for genotoxic alkylating agents? Mutagenesis 20: 389-398.

Kada T and Shimoi K (1987). Desmutagens and bio-antimutagens-their modes of action. Bioessays 7: 113-116.

Kelloff GJ, Crowell JA, Steele VE, Lubet RA, et al. (1999). Progress in cancer chemoprevention. Ann. N. Y. Acad. Sci. 889: $1-13$.

Kohlmeier L, Simonsen N and Mottus K (1995). Dietary modifiers of carcinogenesis. Environ Health Perspect (Suppl 8): 177-184.

Matsumoto ST, Mantovani MS, Malagutti MIA and Dias AL (2006). Genotoxicity and mutagenicity of water contaminated with tannery effluents, as evaluated by the micronucleus test and comet assay using the fish Oreochromis niloticus and chromosome aberrations in onion root-tips. Genet. Mol. Biol. 29: 148-158.

Maxwell SR (1995). Prospects for the use of antioxidant therapies. Drugs 49: 345-361.

Offord EA, Macé K, Ruffieux C, Malnoë A, et al. (1995). Rosemary components inhibit benzo[a]pyrene-induced genotoxicity in human bronchial cells. Carcinogenesis 16: 2057-2062.

Oga S, Camargo MMA and Batistuzzo JAO (2008). Fundamentos de Toxicologia. 3rd edn. Atheneu, São Paulo.

Oliveira RJ, Ribeiro LR, da Silva AF, Matuo R, et al. (2006). Evaluation of antimutagenic activity and mechanisms of action of $\beta$-glucan from barley, in CHO-k1 and HTC cell lines using the micronucleus test. Toxicol. In Vitro 20 : 1225-1233.

Oliveira RJ, Matuo R, da Silva AF, Matiazi HJ, et al. (2007). Protective effect of $\beta$-glucan extracted from Saccharomyces cerevisiae, against DNA damage and cytotoxicity in wild-type (k1) and repair-deficient (xrs5) CHO cells. Toxicol. In Vitro 21: 41-52.

Oliveira RJ, Baise E, Mauro MO, Pesarini JR, et al. (2009). Evaluation of chemopreventive activity of glutamine by the comet and the micronucleus assay in mice's peripheral blood. Environ Toxicol. Pharmacol. 28: 120-124.

Rank J and Nielsen MH (1997). Allium cepa anaphase-telophase root tip chromosome aberration assay on N-methyl-Nnitrosourea, maleic hydrazide, sodium azide, and ethyl methanesulfonate. Mutat. Res. 390: 121-127.

Rigonato J, Mantovani MS and Jordão BQ (2004). Mechanism of action of chlorophyllin against mitomycin-C mutagenicity in Allium cepa. Cytologia 69: 459-495.

Sies H (1993). Strategies of antioxidant defense. Eur. J. Biochem. 215: 213-219.

Singletary KW and Rokusek JT (1997). Tissue-specific enhancement of xenobiotic detoxification enzymes in mice by dietary rosemary extract. Plant Foods Hum. Nutr. 50: 47-53.

Snustad DP and Simmons MJ (2001). Fundamentos de Genética. 2nd edn. Guanabara Koogan, Rio de Janeiro.

Steiner M, Priel I, Giat J, Levy J, et al. (2001). Carnosic acid inhibits proliferation and augments differentiation of human leukemic cells induced by 1,25-dihydroxyvitamin D3 and retinoic acid. Nutr. Cancer 41: 135-144.

Waters MD, Brady AL, Stack HF and Brockman HE (1990). Antimutagenicity profiles for some model compounds. Mutat. Res. 238: 57-85. 